\title{
Platinum(II) $O, S$ Complexes Inhibit the Aggregation of Amyloid Model Systems
}

\author{
Daniele Florio $^{1}$, Anna Maria Malfitano ${ }^{2}$, Sarah Di Somma ${ }^{2}$, Carolin Mügge ${ }^{3,4}{ }^{\circ}$, \\ Wolfgang Weigand $^{3} \mathbb{D}$, Giarita Ferraro ${ }^{5}$, Ilaria Iacobucci ${ }^{5,6}$, Maria Monti ${ }^{5,6}{ }^{\mathbb{D}}$, \\ Giancarlo Morelli ${ }^{1}$, Antonello Merlino ${ }^{5}$ (D) and Daniela Marasco ${ }^{1, *}$ \\ 1 Department of Pharmacy, University of Naples Federico II, 80134 Napoli, Italy; \\ floriodaniele1@gmail.com (D.F.); giancarlo.morelli@unina.it (G.M.) \\ 2 Department of Translational Medical Science, University of Naples Federico II, 80131 Napoli, Italy; \\ annamaria.malfitano@unina.it (A.M.M.); sarah.disomma@unina.it (S.D.S.) \\ 3 Institute for Inorganic and Analytical Chemistry, University of Jena, 07743 Jena, Germany; \\ carolin.muegge@rub.de (C.M.); wolfgang.weigand@uni-jena.de (W.W.) \\ 4 Department of Biology, Ruhr-University Bochum, 44801 Bochum, Germany \\ 5 Department of Chemical Sciences, University of Naples Federico II, 80126 Napoli, Italy; \\ giarita.ferraro@gmail.com (G.F.); ilaria.iacobucci@unina.it (I.I.); montimar@unina.it (M.M.); \\ antonello.merlino@unina.it (A.M.) \\ 6 CEINGE Biotecnologie Avanzate s.c.a r.l., University of Naples Federico II, 80145 Napoli, Italy \\ * Correspondence: daniela.marasco@unina.it; Tel.: +39-0812534607
}

Received: 11 January 2019; Accepted: 13 February 2019; Published: 14 February 2019

\begin{abstract}
Platinum(II) complexes with different cinnamic acid derivatives as ligands were investigated for their ability to inhibit the aggregation process of amyloid systems derived from $A \beta$, Yeast Prion Protein Sup35p and the C-terminal domain of nucleophosmin 1. Thioflavin T binding assays and circular dichroism data indicate that these compounds strongly inhibit the aggregation of investigated peptides exhibiting $\mathrm{IC}_{50}$ values in the micromolar range. MS analysis confirms the formation of adducts between peptides and $\mathrm{Pt}$ (II) complexes that are also able to reduce amyloid cytotoxicity in human SH-SY5Y neuroblastoma cells. Overall data suggests that bidentate ligands based on $\beta$-hydroxy dithiocinnamic esters can be used to develop platinum or platinoid compounds with anti-amyloid aggregation properties.
\end{abstract}

Keywords: amyloid aggregation; platinum complexes; anti-aggregation properties

\section{Introduction}

The mechanism of action (MOA) of $\mathrm{Pt}(\mathrm{II})$-based anticancer agents, among which cisplatin [cis- $\mathrm{Pt}\left(\mathrm{NH}_{3}\right)_{2} \mathrm{Cl}_{2}$ ] is recognized as a progenitor, is well known. It consists of "DNA platination", i.e., the exchange of a chlorido ligand of the first coordination sphere of $\mathrm{Pt}(\mathrm{II})$ with a nucleobase of DNA (for example a guanine) [1]. However, these metal compounds can also interact with proteins and peptides. Crystallographic studies have provided detailed information about the structure of the adducts formed in the reaction of proteins with cisplatin [2-5], trans-Pt complexes [6], cis- $\mathrm{Pt}\left(\mathrm{NH}_{3}\right)_{2} \mathrm{I}_{2}$ [7], carboplatin [2-4,8,9], oxaliplatin [10] and other $\mathrm{Pt}(\mathrm{II})$ complexes, like those bearing $O, S$-bidentate [11,12] or terpyridine ligands [13]. The ligands coordinated to $\mathrm{Pt}(\mathrm{II})$ determine the reactivity of these complexes with proteins and the binding sites. For example, in the interaction with the model protein hen egg white lysozyme (HEWL), cisplatin $[3,13,14]$, carboplatin, trans-Pt derivatives [8,13] and cis-Pt $\left(\mathrm{NH}_{3}\right)_{2} \mathrm{I}_{2}[8,15]$ bind His15, oxaliplatin binds Asp119 [16,17], whereas a $\mathrm{Pt}(\mathrm{II})$ terpyridine compound binds the side chains of Lys1, Glu7, His15, Arg14 and His15, Lys13, 
Lys96, Lys97 and Asn93 [13]. These bioinorganic complexes were also investigated in their kinetic and thermodynamic features [14-16].

Beyond their use as anticancer drugs, Pt(II) complexes have been studied for a number of activities [17] including antibacterial and antiparasitic purposes. Furthermore, they could act as potential therapeutics for amyloid-neurodegenerative diseases [18,19]. A pioneering study has demonstrated that phenanthroline-based complexes (Pt-phen, phen $=1,10$-phenanthroline) coordinate at the His residues of $A \beta_{1-40}$ and act as potent inhibitors of $A \beta$ aggregation and neurotoxicity, restoring the cell viability of primary mouse cortical neurons [20]. Although the interaction between Pt-phen complexes and $A \beta$ is relatively weak, the coordination of these compounds to the peptide significantly alters its aggregation propensity and toxicity profile, as well as its ability to bind $\mathrm{Cu}(\mathrm{I}, \mathrm{II})$ and $\mathrm{Zn}(\mathrm{II})$ [21-23].

Several studies have suggested that the potential therapeutic effects of $\mathrm{Pt}(\mathrm{II})$ complexes can be tuned by varying the hydrophobicity and charge of the ligands. Indeed, both the inhibition of the fibrillogenesis as well as the arrest of self-recognition during the aggregation process were observed [24].

Platinoid complexes, such as $\mathrm{Ru}(\mathrm{II}), \mathrm{Ir}(\mathrm{III})$ and $\mathrm{Rh}(\mathrm{III})$ compounds, are also good inhibitors of amyloid fiber formation [25]. Ruthenium complexes are often alternatives to Pt-based drugs for the treatment of cancer and have been evaluated for their potential applications in neurodegenerative diseases [26-28]. Similarly, octahedral $\operatorname{Ir}(\mathrm{III})$ and $\mathrm{Rh}(\mathrm{III})$ compounds with the same binuclear ligands [25] are able to rescue the toxicity of $A \beta_{1-42}$ in primary cortical neurons [29] and can act as photo-modulators of amyloid-like aggregation [30]. On the other hand, Co(III) Schiff base complexes are able to bind $A \beta$ sequences through His coordination [31] and to promote hydrolysis of peptide sequences [32].

The MOA of both $\mathrm{Pt}$ and platinoid complexes is associated with a direct interaction of the metallodrug with the amyloidogenic monomer that determines a rearrangement of its structure to a species less prone to aggregate. In this respect, it is crucial that the metal complexes undergo ligand(s) substitutions with protein residue side chains, such as the imidazole ring of His, which is the main target for platinoid complexes. Thus, the spatial arrangement of labile positions plays an important role. Two labile positions in cis conformation on a cyclometalated Pt(II) complex allows targeting Glu and His residues of $A \beta$ [20]; similarly, two labile cis coordinated ligands in Pt-phen complexes [33,34] are responsible for the coordination of the side chains of Asp7, His13, and Lys16 for a short $A \beta$ variant encompassing residues 1-16 (A $\left.\beta_{1-16}\right)$ [35]. The presence of aromatic rings in ligands also allows the formation of aromatic interactions (e. g. $\pi-\pi$ interactions) with Phe, His and Tyr side chains of $A \beta$, as demonstrated by the reaction of $\mathrm{Pt}(\mathrm{phen}) \mathrm{Cl}_{2}$ with $\mathrm{A} \beta_{1-16}$. Indeed, $\mathrm{Pt}$-phen complexes were found to coordinate the imidazole group of His6 and His14, whereas cisplatin preferentially binds the side chain of Met35 of $A \beta$ [35-37].

However, $\mathrm{A} \beta$ peptides are not the only targets as amyloid systems. The aggregation of the peptide spanning residues $106-126$ of Prion Protein $\left(\mathrm{PrP}_{106-126}\right)$ can be inhibited by its interaction with the $\mathrm{Ru}(\mathrm{III})$ complex NAMI-A or by its analogues [38]. Similarly, it has been demonstrated that the amyloid aggregation of human islet amyloid polypeptide (hIAPP) can be inhibited by metal complexes containing homo-dinuclear $\mathrm{Ru}[39,40]$ and hetero-multinuclear Pt-Ru systems [41]. In these cases, the binding of metal complexes to hIAPP produces a spontaneous, enthalpy-driven process, due to both hydrophobic interactions and metal coordination.

Here we focus our attention on a series of $\mathrm{Pt}(\mathrm{II})$ compounds bearing a conserved $O, S$ binding moiety, based on $\beta$-hydroxy dithiocinnamic esters, as a bidentate ligand (Figure 1). These compounds are appreciably stable in mixed dimethyl sulfoxide-aqueous solvents [11] and cytotoxic for cisplatin resistant cell lines, suggesting a different MOA when compared to cisplatin [42]. To investigate the inhibitory potentials of these molecules on the aggregation of amyloid peptides, we employed three different sequences: (1) the peptide fragment corresponding to the helix H2 (residues 264-277) of C-terminal domain of nucleophosmin 1 (NPM1 $\left.1_{264-277}\right)$, which shows a remarkable tendency to 
form amyloid-like assemblies endowed with fibrillar morphology and $\beta$-sheet structure toxic to neuroblastoma cells [43-48], (2) the heptapetide GNNQQNY, spanning residues 7-13 of the Yeast Prion Protein Sup35p (Sup35 $p_{7-13}$ ), which is involved in the aggregation of Sup35p [49] and (3) the fragment consisting of residues $21-40$ of $\mathrm{A} \beta\left(\mathrm{A} \beta_{21-40}\right)$ [50]. The three chosen protein fragments are involved in the aggregation mechanism of the related entire proteins.

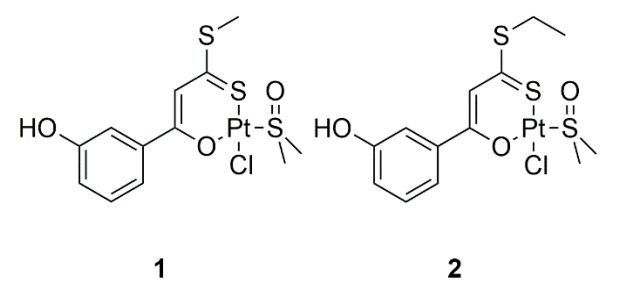

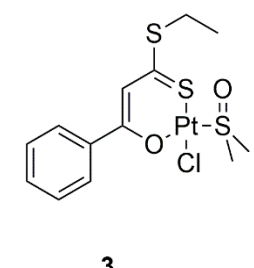

3

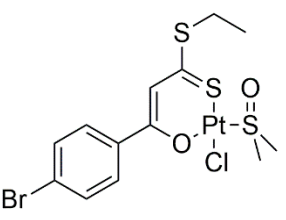

4

Figure 1. Chemical structures of $\mathrm{Pt}(\mathrm{II})$ complexes used in this work.

\section{Results and Discussion}

\subsection{Pt(II) Complexes with Bidentate Ligands Inhibit the Aggregation of Amyloidogenic Peptides}

The ability of the $\mathrm{Pt}(\mathrm{II})$ complexes reported in Figure 1 to inhibit the aggregation process of the investigated amyloid peptides was evaluated through fluorescence spectroscopy. Sequences and isoelectric points of the analyzed peptides are reported in Table 1.

Table 1. Peptide sequences analyzed in this study.

\begin{tabular}{ccc}
\hline Peptide & Sequence & pI \\
\hline $\mathrm{NPM}_{264-277}$ & VEAKFINYVKNCFR & 9.2 \\
$\mathrm{Sup35} \mathrm{p}_{7-13}$ & GNNQQNY & 5.5 \\
$\mathrm{~A} \beta_{21-40}$ & AEDVGSNKGAIIGLMVGGVV & 4.5 \\
\hline
\end{tabular}

Thioflavin T (ThT) binding assay was employed; it is frequently used to analyze the kinetic of the self-recognition process associated with amyloid fibers formation [51].

The time course of the ThT fluorescence when NPM1 $1_{264-277}$ is incubated with the complexes $\mathbf{1 , 2}$, 3 and $\mathbf{4}$ is reported in Figure 2. Fluorescence values were registered for the peptide in the presence of the different concentrations of the Pt compounds, according to the peptide to $\mathrm{Pt}(\mathrm{II})$ compound molar ratios indicated in the legends.

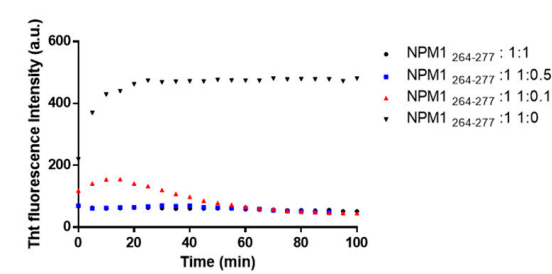

(a)

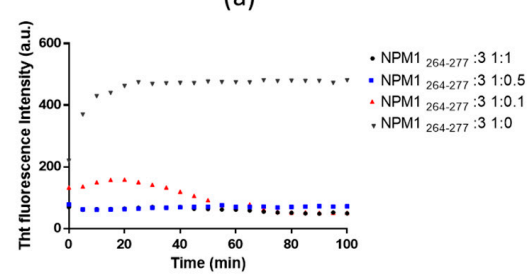

(c)

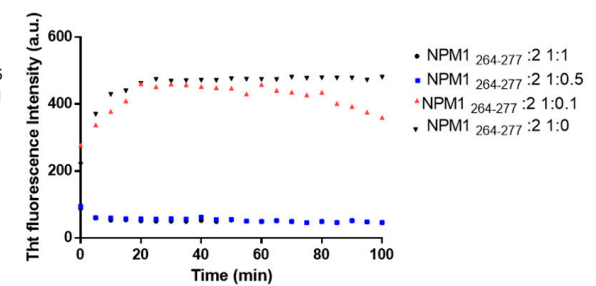

(b)

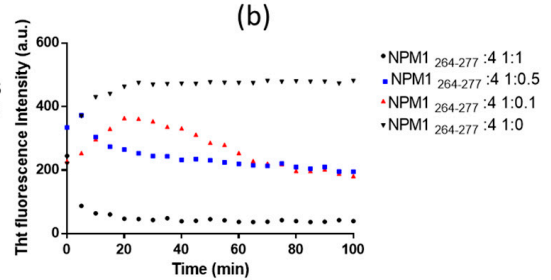

(d)

Figure 2. Time course of Thioflavin $\mathrm{T}(\mathrm{ThT})$ fluorescence emission intensity of NPM1 $1_{264-277}$ upon incubation with different concentrations of (a) 1, (b) 2, (c) 3, (d) 4. The peptide alone is reported as a grey triangle. The peptide incubated with the compounds in 1:1, 1:0.5 and 1:0.1 peptide to metal complex molar ratio are reported as a black circle, blue square and red triangle, respectively. 
$\mathrm{NPM}_{264-277}$ alone, pre-treated with hexafluoroisopropanol (HFIP), exhibits a $t_{1 / 2}$ value for aggregation of $7 \mathrm{~min}$, as reported in Table 2. When NPM1 $1_{264-277}$ is treated with the Pt compounds at a molar ratio of 1:1, a clear inhibitor effect is observed. The inhibition of the aggregation is faster for compounds 1 and $\mathbf{3}$ (Figure 2a,c) than for $\mathbf{2}$ and $\mathbf{4}$ (Figure 2b,d). In the case of $\mathbf{1}$ and 3, the ThT fluorescence value decreases in less than $5 \mathrm{~min}$, whereas it reduces after $5 \mathrm{~min}$ and $20 \mathrm{~min}$ in the case of 2 and 4, respectively. The complete decrease of the fluorescence signal at $481 \mathrm{~nm}$ over time of the ThT/NPM1 264-277 systems in the presence of different Pt complexes suggests that the sample remains in the same monomeric state when treated with Pt compounds at 1:1 equivalents (Table 2).

Table 2. Aggregation kinetics $\left(t_{\frac{1}{2}}\right)$ and maximum fluorescence intensities of NPM1 $264-277$ following ThT emission at indicated peptide:Pt compounds molar ratios.

\begin{tabular}{|c|c|c|c|}
\hline & $\begin{array}{l}\text { Peptide to Pt } \\
\text { Compound Ratio }\end{array}$ & $t_{1 / 2}(\min )$ & $\begin{array}{l}\text { Fluorescence Intensity } \\
\text { (Arbitrary Unit) }\end{array}$ \\
\hline $\mathrm{NPM}_{264-277}$ & & 5 & 568 \\
\hline $\mathrm{NPM}_{264-277}: 1$ & 1:0.1 & 6.5 & 155 \\
\hline $\mathrm{NPM1}_{264-277}: 1$ & 1:0.5 & n.d. & 45 \\
\hline $\mathrm{NPM}_{264-277}: \mathbf{1}$ & $1: 1$ & n. d. & 45 \\
\hline $\mathrm{NPM}_{264-277}: 2$ & 1:0.1 & 7 & 410 \\
\hline $\mathrm{NPM}_{264-277}: 2$ & 1:0.5 & n.d. & 49 \\
\hline $\mathrm{NPM}_{264-277}: 2$ & $1: 1$ & n.d. & 48 \\
\hline $\mathrm{NPM}_{264-277}: 3$ & 1:0.1 & 6 & 155 \\
\hline $\mathrm{NPM}_{264-277}: 3$ & 1:0.5 & n.d. & 70 \\
\hline $\mathrm{NPM}_{264-277}: 3$ & $1: 1$ & n.d. & 64 \\
\hline $\mathrm{NPM}_{264-277}: 4$ & 1:0.1 & 10 & 363 \\
\hline $\mathrm{NPM1}_{264-277}: 4$ & 1:0.5 & n.d. & 220 \\
\hline $\mathrm{NPM1}_{264-277}: 4$ & $1: 1$ & n.d. & 43 \\
\hline
\end{tabular}

On the other hand, the anti-aggregation abilities of the investigated compounds are different at lower peptide to Pt complex molar ratios. When NPM1 $1_{264-277}$ is treated with $\mathbf{1}$ and $\mathbf{3}$ at 1:0.1, molar ratio its aggregation is completely inhibited after $50 \mathrm{~min}$. On the contrary, when it is treated with 2 and 4, the inhibition of the amyloid aggregation is not completed in the investigated time scales. Furthermore, at 1:0.5 peptide to metal complex molar ratio, NPM1 $1_{264-277}$ provides ThT signals similar to those observed at 1:1 molar ratio in the presence of 1, 2 and 3, while it shows a ThT signal that suggests an incomplete inhibition of the aggregation process in the presence of 4 . Potential variations of the fluorescence intensity of ThT caused by $\mathrm{Pt}(\mathrm{II})$ complexes are negligible and comparable to the blank signal registered in absence of the complexes.

This analysis indicates that $\mathbf{1}$ and $\mathbf{3}$ are the most effective inhibitors for amyloid aggregation of $\mathrm{NPM1}_{264-277}$; therefore 1 was chosen for further analyses.

To verify if $\mathbf{1}$ could have a similar inhibitory effect on other amyloid systems, the ThT assay was also carried out using Sup35 $p_{7-13}$ (Table 1). The time courses of the ThT signals of Sup35 $p_{7-13}$, in the presence and in the absence of $\mathbf{1}$ are reported in Figure 3. The ThT fluorescence intensity of the peptide alone displays two distinct transitions, suggesting a seeding effect of first soluble aggregates to secondly achieve higher levels of oligomerization, as already suggested by other studies [52].

Comparing the ThT signal of the peptide alone with that observed in the presence of $\mathbf{1}$, it is clear that the Pt compound affects the aggregation process of Sup35p $\mathrm{p}_{7-13}$, leading to species with a lower oligomeric state than those found in the case of the peptide alone.

We have also evaluated the ability of $\mathbf{1}$ to disaggregate soluble amyloid oligomers, monitoring the ThT signals versus time upon the addition of $\mathbf{1}$ to NPM1 $1_{264-277}$ and Sup35p $\mathrm{p}_{7-13}$ aggregates (Figure 4). The two peptides have different aggregation kinetics, due to their differences in sequence and structure. For this reason, Sup35 $\mathrm{p}_{7-13}$ was pre-aggregated in the absence of the complexes for one night, whereas $\mathrm{NPM} 1_{264-277}$ was partially aggregated at $t_{0}$ as already reported [43]. Interestingly, we observed a 
decrease of ThT fluorescence intensity upon the addition of $\mathbf{1}$ for both peptides. These findings clearly indicate the disaggregating ability of the compound for both amyloid systems.

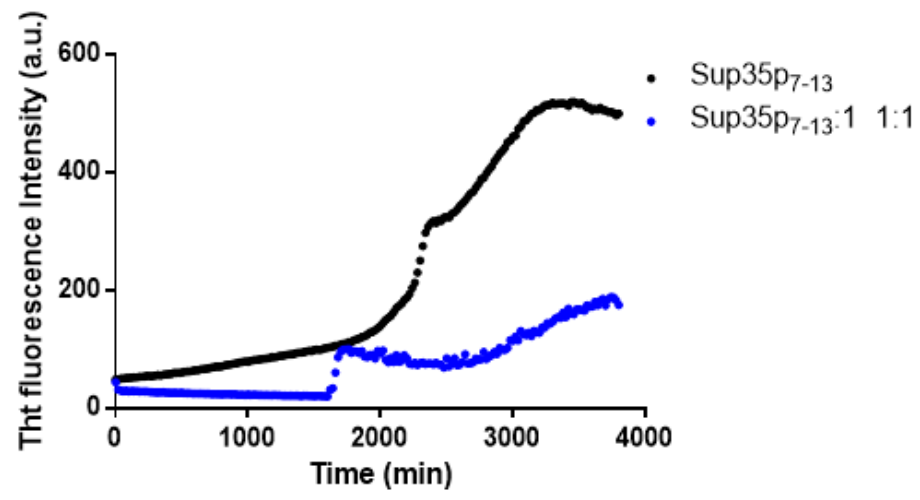

Figure 3. Time course of ThT fluorescence emission intensity of Sup35p $\mathrm{p}_{7-13}$ (black) upon incubation with 1 at 1:1 peptide to $\mathrm{Pt}$ compound ratio (blue).

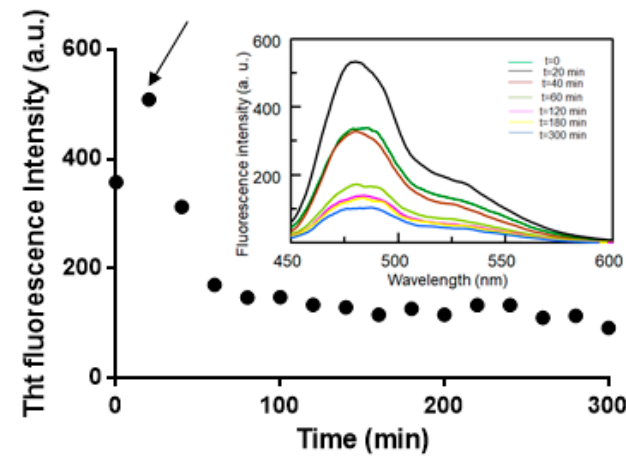

(a)

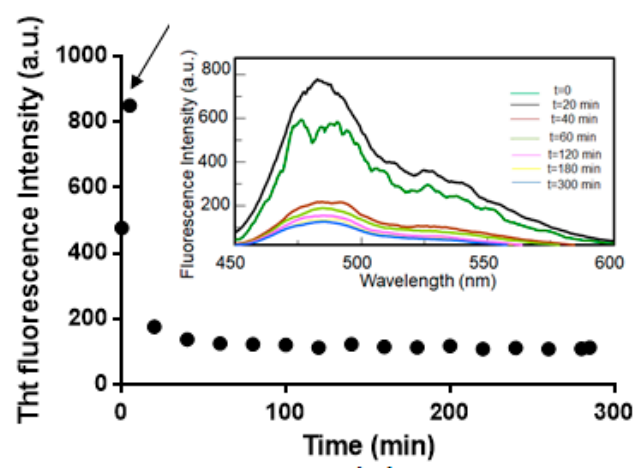

(b)

Figure 4. Time course of ThT fluorescence emission intensity of NPM1 $1_{264-277}$ (a) and Sup35p $\mathrm{p}_{7-13}$ (b) upon the addition of $\mathbf{1}$. The time of addition of $\mathbf{1}$ is indicated by an arrow. In the inset, an overlay of the spectra at indicated times are reported.

A similar experiment was performed using $A \beta_{21-40}$. For this peptide, the ThT fluorescence signal as function of time is reported in Figure 5. The addition of $\mathbf{1}$ to soluble aggregates of $A \beta_{21-40}$, formed within $1000 \mathrm{~min}$ resulted in an instantaneous decrease of the fluorescence intensity, which indicates a disaggregating effect.

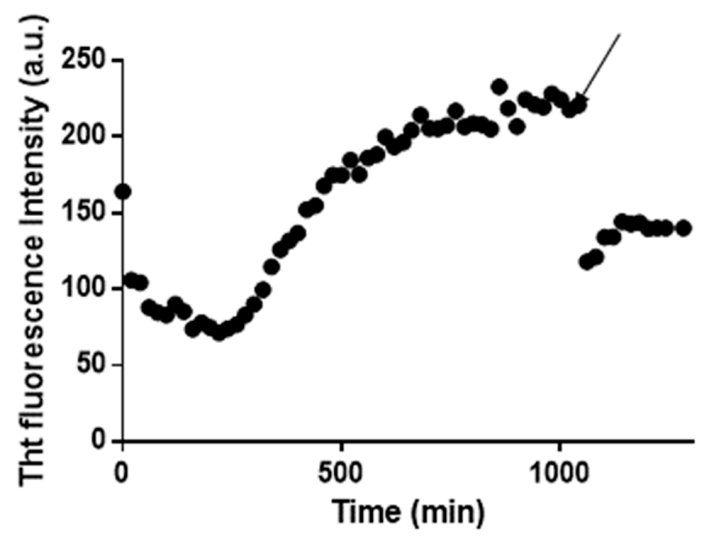

Figure 5. The ThT fluorescence profile of the formation of amyloid aggregates of $A \beta_{21-40}$ and their disaggregation upon the addition of 1 at 1:1 peptide to $\mathrm{Pt}$ compound molar ratio. The time of addition of the $\mathrm{Pt}(\mathrm{II})$ compound is indicated by an arrow. 
The ability of 0.9 to dose-dependently inhibit the aggregation of $\mathrm{NPM}_{264-277}, \mathrm{Sup}_{35} \mathrm{p}_{7-13}$ and $\mathrm{A} \beta_{21-40}$ was quantitatively assessed through the comparison of experimental ThT fluorescence values [53], using different metal compound concentrations. The best fittings of experimental data, reported in Figure 6, provide $\mathrm{IC}_{50}$ values of $62.3 \pm 1.3,55.03 \pm 1.12,19.9 \pm 1.6 \mu \mathrm{M}$ for $\mathrm{NPM1}_{264-277}$, Sup35 $p_{7-13}$ and $A \beta_{21-40}$, respectively.

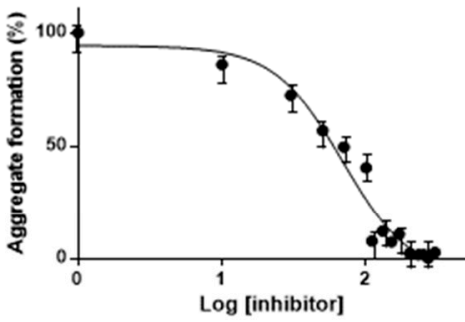

(a)

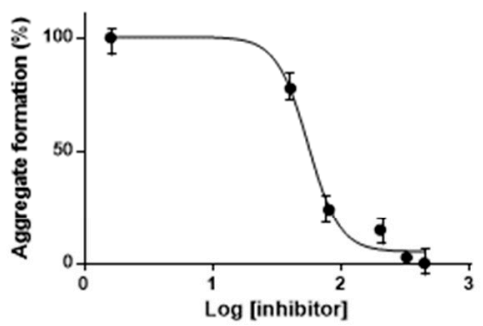

(b)

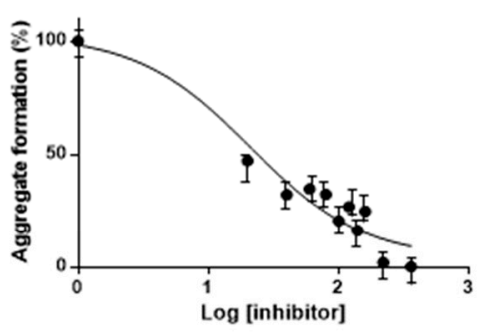

(c)

Figure 6. Inhibition of $\mathrm{NPM} 1_{264-277}(\mathbf{a})$, Sup35p $\mathrm{p}_{7-13}(\mathbf{b})$ and $\mathrm{A} \beta_{21-40}$ (c) aggregation upon the addition of 1 , measured as a percentage variation of ThT fluorescence. $\mathrm{IC}_{50}$ values were derived from non-linear regression fit of the data $\left(r^{2} \geq 0.98\right)$ by fixing the maximum and minimum values at 100 and $0 \%$, respectively, and allowing the Hill slope to vary. Results are representative of two independent experiments.

\subsection{Pt Complexes Inhibit Conformational $\beta$-Transition}

The inhibitory effects of $\mathbf{1}$ and of the other Pt compounds here investigated could be associated with conformational variations of the analyzed peptides. To study these potential conformational variations, circular dichroism (CD) spectra of NPM1 $1_{264-277}$ incubated with different equivalents of 1 for one night were compared. CD spectra are superimposed in Figure 7a.

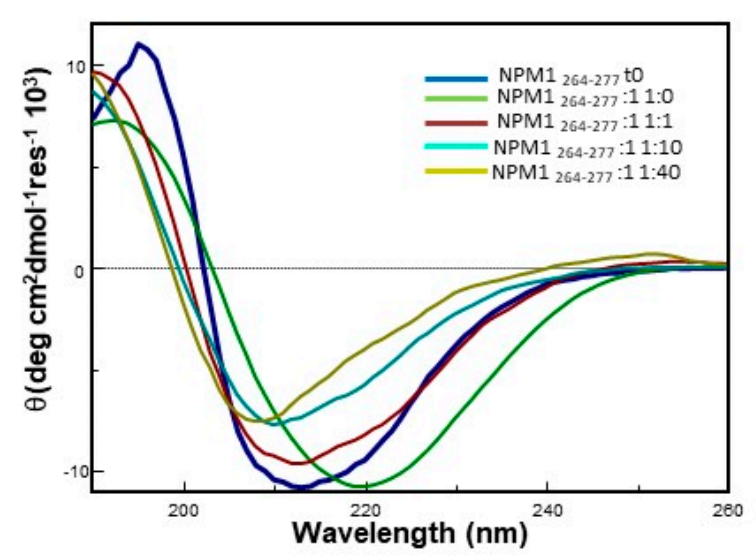

(a)

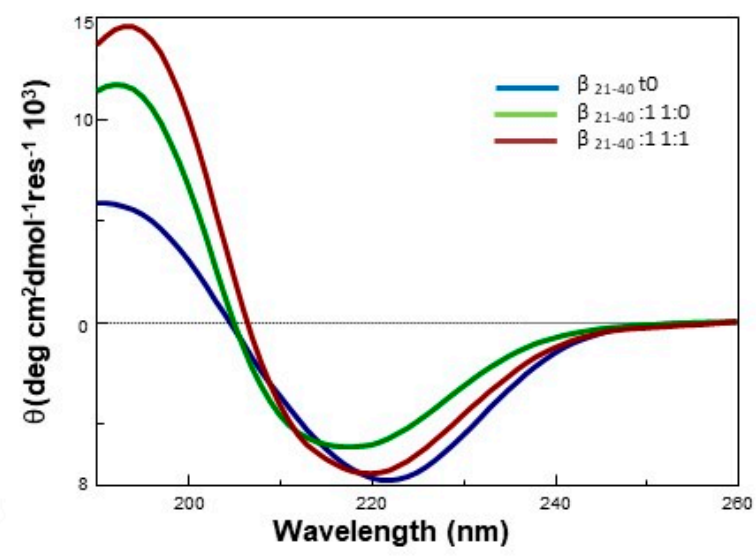

(b)

Figure 7. Overlay of CD spectra of (a) NPM1 $1_{264-277}$ and (b) $A \beta_{21-40}$ incubated under stirring with 1 at different peptide to $\mathrm{Pt}$ compound molar ratio. Incubation time: overnight.

A transition from a mixed $\alpha$-helix + random coil structure towards a $\beta$-sheet structure was previously demonstrated for a variant of NPM1 $1_{264-277}$ which includes helix 2 and the loop between the 1st and the 2nd helix of the bundle of the C-terminal domain of NPM1 [35].

The spectra of NPM1 $1_{264-277}$ indicate that, upon overnight incubation, the peptide fibrillates and converts from $\alpha$-helix to $\beta$-sheet (green vs. blue line in Figure 7a). Notably, the presence of the Pt compounds inhibits the $\alpha$-helix to $\beta$-sheet conversion at all the investigated NPM1 $264-277$ :metal compound molar ratios. Indeed, spectra of $\mathrm{NPM}_{264-277}$ in the presence of the Pt compounds show 
minima at wavelengths $\leq 210 \mathrm{~nm}$ (Figure 7a), which are diagnostic of the presence of a significant helical content and suggest the formation of ligand-specific secondary structures. A similar behavior has been previously observed when other Pt compounds interacted with $A \beta$ peptides [42].

The same experiment was carried out using $A \beta_{21-40}$. CD spectra of freshly prepared samples of this peptide are already indicative of the presence of a $\beta$-structure, as reported in Figure $7 \mathrm{~b}$ (blue line), thus precluding the possibility to follow the $\alpha$-helix to $\beta$-sheet transition. However, it is interesting to note that the spectrum of the sample corresponding to $A \beta_{21-40}: 1$ in 1:1 molar ratio, after one night of incubation, is more similar to that of the freshly prepared sample of $A \beta_{21-40}$ than to that of $A \beta_{21-40}$ incubated for one night in the absence of $\mathbf{1}$.

Attempts to carry out similar experiments using Sup $35 p_{7-13}$ failed, since during the aggregation process of this peptide only a significant decrease of the Cotton effect occurred [52] and no substantial differences were observed when the peptide was incubated in presence of $\mathbf{1}$.

\subsection{Mass Spectrometry Analysis}

The peptides and selected Pt compounds (1 and 3) at 1:10 ratio, were incubated for $24 \mathrm{~h}$ and analyzed by electrospray ionization mass spectrometry (ESI-MS) [54]. As an example, a portion of the spectra obtained for $\mathrm{A} \beta_{21-40}$ incubated with $\mathbf{1}$ is reported in Figure 8.

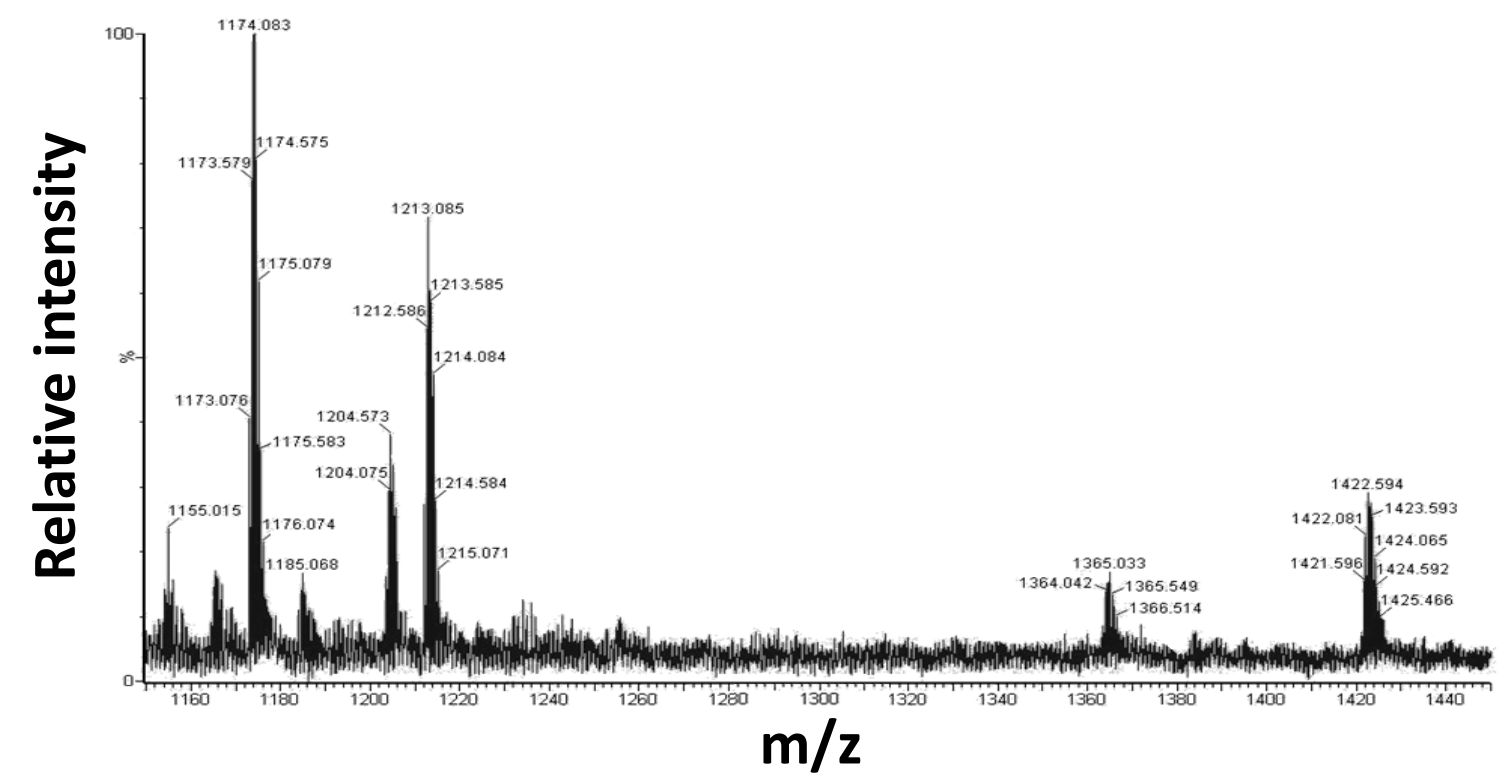

Figure 8. Electrospray ionization mass spectrometry (ESI) spectrum of A $\beta_{21-40}$ with 1, after $24 \mathrm{~h}$ of incubation. All signals are generated from double charged ions.

The presence of double charged signals at 1173.076 and $1212.586 \mathrm{~m} / \mathrm{z}$ confirms the formation of adducts between $A \beta_{21-40}$ and 1 at 1:1 molar ratio, which are formed upon the release of the chloride and DMSO or solely the chloride, respectively. Furthermore, the signal at $1421.596 \mathrm{~m} / \mathrm{z}$ corresponds to the double charged peptide ion generated by $\mathrm{A} \beta_{21-40}$ bound to $2 \mathrm{Pt}$ complexes, one with the release of the chloride and the other missing a chloride and DMSO. The theoretical and measured molecular masses are reported in Table 3. 
Table 3. Results of the ESI-MS analysis of the adducts formed by $A \beta_{21-40}$ and 1 . The experimental $\mathrm{m} / \mathrm{z}$ values, the ion charge status, the experimental and theoretical monoisotopic mass values and the corresponding ion species are reported.

\begin{tabular}{cccc}
\hline $\begin{array}{c}\text { Experimental } \mathbf{m} / \mathbf{z}, \\
\text { Charge }\end{array}$ & $\begin{array}{c}\text { Experimental } \\
\text { Monoisotopic Mass } \\
\text { (Da) }\end{array}$ & $\begin{array}{c}\text { Theoretical } \\
\text { Monoisotopic Mass } \\
\text { (Da) }\end{array}$ & Pt(II)-Peptide Complexes \\
\hline $1173.056,+2$ & 2344.15 & 2346.39 & $\mathrm{~A} \beta_{21-40}+1 \times(\mathbf{1})-1 \mathrm{Cl}-1 \mathrm{DMSO}$ \\
\hline $1212.586,+2$ & 2422.16 & 2424.52 & $\mathrm{~A} \beta_{21-40}+1 \times(\mathbf{1})-1 \mathrm{Cl}$ \\
\hline $1421.596,+2$ & 2841.16 & 2844.90 & $\mathrm{~A} \beta_{21-40}+2 \times(\mathbf{1})-2 \mathrm{Cl}-1 \mathrm{DMSO}$ \\
\hline
\end{tabular}

Noticeably the sequence NPM1 $1_{264-277}$ revealed the ability to form adducts with two, three or four Pt derivatives for both compounds $\mathbf{1}$ and $\mathbf{3}$. Results are reported in supplementary Tables S1 and S2.

\subsection{Inhibition of Cytotoxic Effects of NPM1 $264-277$ Peptide in SH-SY5Y Cells}

The ability of the $\mathrm{Pt}(\mathrm{II})$ complexes to reduce the neurotoxicity of the NPM1 $264-277$ peptide was assessed using human SH-SY5Y neuroblastoma cells. Cell survival was evaluated after treating SH-SY5Y cells with the peptide alone or with the mixture of the peptide and $\mathrm{Pt}(\mathrm{II})$ complexes.

In comparison with the control sample, the aggregated NPM1 264-277 peptide showed the highest toxicity at $2 \mathrm{~h}$ (cell viability $<75 \%$ ), becoming less effective after $24 \mathrm{~h}$ of incubation (cell viability $<82 \%$ ), probably because of the conversion of the early aggregates into larger and less toxic aggregates as already reported for similar amyloids [55] and for NPM1264-277 peptide [43].

Compounds 1 and 3 incubated with NPM1 $1_{264-277}$, at 1:10 molar ratio, seemed to have a protective function against the toxicity induced by the amyloid peptide. Indeed, their presence increased the cell viability values similar to untreated cells (Figure 9), as already reported for similar platinoid compounds [56].

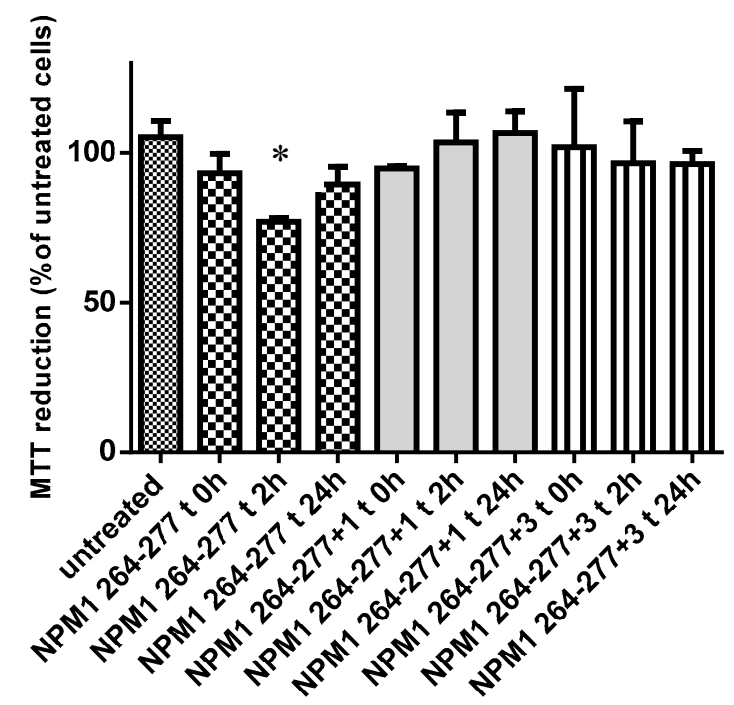

Figure 9. MTT assay in SH-SY5Y cells treated with NPM1 $264-277$ and NPM1 $264-277$ :Pt compounds at 1:10 peptide to metal compounds molar ratio under stirring at three different times, 0,2 and $24 \mathrm{~h}$, ${ }^{*} p<0.05$ in statistical analysis.

\section{Materials and Methods}

\subsection{Peptide Synthesis}

Amyloid peptides analyzed in this study were synthesized as already reported [35,43]. Their sequences are reported in Table 1. Reagents for peptide synthesis were from Iris Biotech (Marktredwitz, 
Germany), solvents for peptide synthesis and HPLC analyses were from Romil (Dublin, Ireland); reversed phase columns for peptide analysis and the LC-MS system were from ThermoFisher (Waltham, MA, USA). Peptides' purity and identity were confirmed by LC-MS. Purified peptides were lyophilized and stored at $-20^{\circ} \mathrm{C}$ until use. Prior to be analyzed they were all treated for $30 \mathrm{~min}$ with HFIP to ensure a monomeric state (at 50\% $(v / v)$ in water), and then the organic solvent was removed by evaporation.

\subsection{Synthesis of the Complexes}

The Pt compounds were synthetized as previously described [11,12]. The stability of the compound under the investigated experimental conditions were tested using UV-Vis absorption spectroscopy, as previously done in ref [11].

\subsection{Fluorescence Assays}

Fluorescence assays were carried out at $25^{\circ} \mathrm{C}$ for NPM1 $1_{264-277}$ and $\mathrm{A} \beta_{21-40}$ using the peptide at a concentration of $100 \mu \mathrm{M}$ and for Sup35 $\mathrm{p}_{7-13}$ using the peptide at a concentration of $400 \mu \mathrm{M}$ under the following experimental conditions: $10 \mathrm{mM}$ borate buffer at $\mathrm{pH}=9.0,10 \% \mathrm{DMSO}$ for $\mathrm{NPM}_{264-277}$ and $10 \mathrm{mM}$ phosphate buffer at $\mathrm{pH}=7.4,0.3 \% \mathrm{DMSO}$ for $\mathrm{A} \beta_{21-40}$ and Sup35p $\mathrm{p}_{7-13}$. ThT $\left(\lambda_{\text {exc: }}=440 \mathrm{~nm}, \lambda_{\text {emis }}:=481 \mathrm{~nm}\right)$ fluorescence was measured using a Jasco FP 8300 spectrofluorometer in a $10 \mathrm{~mm}$ path-length quartz cuvette, under magnetic stirring. Measurements were collected every $20 \mathrm{~min}$ at indicated time intervals. $50 \mu \mathrm{M}$ ThT was used. Results are representative of two independent experiments.

$\mathrm{IC}_{50}$ value was derived from nonlinear regression of the data employing log (inhibitor) vs. response with GraphPad program [57].

\subsection{Far-UV CD Spectroscopy}

CD spectra of NPM1 $264-277$ (100 $\mu \mathrm{M}, 10 \mathrm{mM}$ borate buffer), Sup35p buffer), $\mathrm{A} \beta_{21-40}(100 \mu \mathrm{M}, 10 \mathrm{mM}$ phosphate buffer), were recorded on a Jasco J-815 spectropolarimeter (JASCO, Tokyo, Japan), using a $0.1 \mathrm{~cm}$ path-length quartz cuvette and different amounts of 1 dissolved in $\mathrm{CH}_{3} \mathrm{CN}$. The Pt complex was incubated with the peptide for one night; organic solvent was removed through vacuum-evaporation. CD spectra were acquired in the far-UV region and processed as already reported [43].

\subsection{Cell Culture}

Human SH-SY5Y neuroblastoma cells (A.T.C.C., Manassas, VA, USA) were cultured in DMEM, supplemented with $10 \%$ FBS, $1.0 \mathrm{mM}$ glutamine and antibiotics. Cell cultures were maintained in a $5.0 \% \mathrm{CO}_{2}$ humidified atmosphere at $37^{\circ} \mathrm{C}$ and grown until they reached $80 \%$ confluence for a maximum of 20 passages.

\subsection{MTT Reduction Assay}

$\mathrm{NPM}_{264-277}(400 \mu \mathrm{M})$ peptide was incubated in $50 \mathrm{mM}$ borate buffer under stirring and samples at 1:10 peptide to ligand molar ratio were retrieved at four different times: 0,2 and $24 \mathrm{~h}$. These were then diluted into cell culture media at a $100 \mu \mathrm{M}$, and then added to SH-SY5Y cells seeded in 96-well plates for $24 \mathrm{~h}$ at $37{ }^{\circ} \mathrm{C}$. Cell viability was then assessed by the 3-(4,5-dimethylthiazol-2-yl)-2,5-diphenyltetrazolium bromide (MTT) reduction assay as previously described [43].

\subsection{ESI MS Analysis of the Complexes}

Solutions of NPM1 $1_{264-277}$, Sup35 $p_{7-13}$ and $A \beta_{21-40}$ at a concentration of $100 \mu \mathrm{M}$ in $10 \mathrm{mM}$ borate buffer at $\mathrm{pH}=9.0,10 \%$ DMSO for $\mathrm{NPM}_{264-277}$ and $10 \mathrm{mM}$ phosphate buffer at $\mathrm{pH}=7.4$, $0.3 \%$ DMSO for $\mathrm{A} \beta_{21-40}$ and Sup35p $\mathrm{p}_{7-13}$ were diluted 10 times in ammonium acetate $15 \mathrm{mM} \mathrm{pH}=7$ 
and analyzed on a Q-ToF Premier (Waters, Milford, MA, USA) by direct injection into the ESI source at a flow of $10 \mu \mathrm{L} / \mathrm{min}$. The source parameters were set as follows: capillary voltage $=3.6 \mathrm{kV}$ and cone voltage $=42 \mathrm{kV}$. The acquisition range was set between 600 and $2500 \mathrm{~m} / \mathrm{z}$. All data were processed by using MassLynx 4.1 software (Waters, Milford, MA, USA).

\section{Conclusions}

In conclusion, we have studied the capability of $\mathrm{Pt}(\mathrm{II})$ complexes bearing $\mathrm{O}, S$ bidentate ligands to inhibit the aggregation process of three different amyloidogenic peptides. The results indicate that the $O, S$ bidentate ligands of new Pt or Platinoid complexes are promising compounds able to inhibit aggregation of small model amyloid systems. Future studies on full-length proteins should confirm the anti-aggregation properties of these $\mathrm{Pt}(\mathrm{II})$ compounds and their potential application as drugs in neurodegenerative diseases.

Supplementary Materials: Supplementary materials can be found at http:/ / www.mdpi.com/1422-0067/20/4/ $829 /$ s1.

Author Contributions: A.M. and D.M. designed the concept. D.M. supervised the experiments. D.F., G.F., A.M.M., S.D.S., I.I., M.M. performed the experimental work. C.M. synthetized the metal compounds, with W.W.'s supervision. G.M. provided financial assistance. A.M. and D.M. wrote the manuscript. All authors have read and approved the final version of the manuscript.

Funding: This work was partially supported by the University of Naples Federico II ("000005 ALTRI_DR_409_2017_Rec_Ateneo_prof_MARASCO) to D.M. and A.M. and POR CAMPANIA FESR 2014/2020 "PROGETTO PREMIO INFRASTRUTTURA PER LA MEDICINA DI PRECISIONE IN ONCOLOGIA".

Acknowledgments: We thank Marta Fik of Adam Mickiewicz University, Poznań, Poland, for his helpful discussion on CD experiments and Consorzio Interuniversitario di Ricerca in Chimica dei Metalli nei Sistemi Biologici (C.I.R.C.M.S.B.).

Conflicts of Interest: The authors declare no conflict of interest.

\section{Abbreviations}

\begin{tabular}{|c|c|}
\hline $\mathrm{A} \beta_{1-16}$ & The peptide encompassing residues $1-16$ of the $A \beta$ peptide \\
\hline $\mathrm{A} \beta_{21-40}$ & The peptide encompassing residues $21-40$ of the $A \beta$ peptide \\
\hline cisplatin & cis- $\mathrm{Pt}\left(\mathrm{NH}_{3}\right)_{2} \mathrm{Cl}_{2}$ \\
\hline $\mathrm{CD}$ & circular dichroism \\
\hline hIAPP & human islet amyloid polypeptide \\
\hline $\mathrm{H} 2$ & Helix 2 (residues 264-277) C-terminal domain of nucleophosmin 1 \\
\hline HFIP & hexafluoroisopropanol \\
\hline MOA & Mechanism of action \\
\hline NPM1 & Nucleophosmin 1 \\
\hline $\mathrm{NPM}_{264-277}$ & Residues of helix 2 of Nucleophosmin 1 \\
\hline Pt-phen & Phenanthroline-based Pt compounds \\
\hline phen & 1,10-phenanthroline \\
\hline $\operatorname{PrP}$ & Prion protein \\
\hline Sup35p & Yeast Prion Protein \\
\hline Sup $35 p_{7-13}$ & Residues 7-13 (sequence:GNNQQNY) of Sup35p \\
\hline ThT & thioflavin $\mathrm{T}$ \\
\hline
\end{tabular}

\section{References}

1. Takahara, P.M.; Rosenzweig, A.C.; Frederick, C.A.; Lippard, S.J. Crystal structure of double-stranded DNA containing the major adduct of the anticancer drug cisplatin. Nature 1995, 377, 649-652. [CrossRef] [PubMed]

2. Casini, A.; Mastrobuoni, G.; Temperini, C.; Gabbiani, C.; Francese, S.; Moneti, G.; Supuran, C.T.; Scozzafava, A.; Messori, L. ESI mass spectrometry and X-ray diffraction studies of adducts between anticancer platinum drugs and hen egg white lysozyme. Chem. Commun. 2007, 156-158. [CrossRef] [PubMed] 
3. Tanley, S.W.; Diederichs, K.; Kroon-Batenburg, L.M.; Levy, C.; Schreurs, A.M.; Helliwell, J.R. Carboplatin binding to histidine. Acta Crystallogr. F Struct. Biol. Commun. 2014, 70, 1135-1142. [CrossRef] [PubMed]

4. Tanley, S.W.; Diederichs, K.; Kroon-Batenburg, L.M.; Levy, C.; Schreurs, A.M.; Helliwell, J.R. Response from Tanley et al. to Crystallography and chemistry should always go together: A cautionary tale of protein complexes with cisplatin and carboplatin. Acta Crystallogr. D Biol. Crystallogr. 2015, 71, 1982-1983. [CrossRef]

5. Tanley, S.W.; Helliwell, J.R. Structural dynamics of cisplatin binding to histidine in a protein. Struct. Dynam. 2014, 1, 034701. [CrossRef] [PubMed]

6. Messori, L.; Marzo, T.; Michelucci, E.; Russo Krauss, I.; Navarro-Ranninger, C.; Quiroga, A.G.; Merlino, A. Interactions between anticancer trans-platinum compounds and proteins: Crystal structures and ESI-MS spectra of two protein adducts of trans-(dimethylamino)(methylamino)dichloridoplatinum(II). Inorgan. Chem. 2014, 53, 7806-7808. [CrossRef]

7. Messori, L.; Merlino, A. Cisplatin binding to proteins: Molecular structure of the ribonuclease a adduct. Inorgan. Chem. 2014, 53, 3929-3931. [CrossRef]

8. Zhang, N.; Du, Y.; Cui, M.; Liu, Z.; Liu, S. Comprehensive identification of the binding sites of cisplatin in hen egg white lysozyme. Analyt. Bioanalyt. Chem. 2014, 406, 3537-3549. [CrossRef]

9. Ferraro, G.; Pica, A.; Russo Krauss, I.; Pane, F.; Amoresano, A.; Merlino, A. Effect of temperature on the interaction of cisplatin with the model protein hen egg white lysozyme. J. Biol. Inorgan. Chem. 2016, 21, 433-442. [CrossRef]

10. Messori, L.; Merlino, A. Cisplatin binding to proteins: A structural perspective. Coordin. Chem. Rev. 2016, 315, 67-89. [CrossRef]

11. Mugge, C.; Marzo, T.; Massai, L.; Hildebrandt, J.; Ferraro, G.; Rivera-Fuentes, P.; Metzler-Nolte, N.; Merlino, A.; Messori, L.; Weigand, W. Platinum(II) Complexes with O,S Bidentate Ligands: Biophysical Characterization, Antiproliferative Activity, and Crystallographic Evidence of Protein Binding. Inorgan. Chem. 2015, 54, 8560-8570. [CrossRef] [PubMed]

12. Mugge, C.; Liu, R.; Gorls, H.; Gabbiani, C.; Michelucci, E.; Rudiger, N.; Clement, J.H.; Messori, L.; Weigand, W. Novel platinum(II) compounds with $O, S$ bidentate ligands: Synthesis, characterization, antiproliferative properties and biomolecular interactions. Dalton Transact. 2014, 43, 3072-3086. [CrossRef]

13. Ferraro, G.; Marzo, T.; Infrasca, T.; Cilibrizzi, A.; Vilar, R.; Messori, L.; Merlino, A. A case of extensive protein platination: The reaction of lysozyme with a Pt(ii)-terpyridine complex. Dalton Transact. 2018, 47, 8716-8723. [CrossRef]

14. Ferraro, G.; De Benedictis, I.; Malfitano, A.; Morelli, G.; Novellino, E.; Marasco, D. Interactions of cisplatin analogues with lysozyme: A comparative analysis. Biometals 2017, 30, 733-746. [CrossRef] [PubMed]

15. Marasco, D.; Messori, L.; Marzo, T.; Merlino, A. Oxaliplatin vs. cisplatin: Competition experiments on their binding to lysozyme. Dalton Transact. 2015, 44, 10392-10398. [CrossRef] [PubMed]

16. Russo Krauss, I.; Messori, L.; Cinellu, M.A.; Marasco, D.; Sirignano, R.; Merlino, A. Interactions of gold-based drugs with proteins: The structure and stability of the adduct formed in the reaction between lysozyme and the cytotoxic gold(III) compound Auoxo3. Dalton Transact. 2014, 43, 17483-17488. [CrossRef] [PubMed]

17. Chan, H.; Pearson, C.S.; Green, C.M.; Li, Z.; Zhang, J.; Belfort, G.; Shekhtman, A.; Li, H.M.; Belfort, M. Exploring Intein Inhibition by Platinum Compounds as an Antimicrobial Strategy. J. Biol. Chem. 2016, 291, 22661-22670. [CrossRef]

18. Hayne, D.J.; Lim, S.; Donnelly, P.S. Metal complexes designed to bind to amyloid-beta for the diagnosis and treatment of Alzheimer's disease. Chem. Soc. Rev. 2014, 43, 6701-6715. [CrossRef]

19. Suh, J.M.; Kim, G.; Kang, J.; Lim, M.H. Strategies Employing Transition Metal Complexes To Modulate Amyloid-beta Aggregation. Inorgan. Chem. 2018. [CrossRef]

20. Barnham, K.J.; Kenche, V.B.; Ciccotosto, G.D.; Smith, D.P.; Tew, D.J.; Liu, X.; Perez, K.; Cranston, G.A.; Johanssen, T.J.; Volitakis, I.; et al. Platinum-based inhibitors of amyloid-beta as therapeutic agents for Alzheimer's disease. Proc. Nat. Acad. Sci. USA 2008, 105, 6813-6818. [CrossRef]

21. Telpoukhovskaia, M.A.; Orvig, C. Werner coordination chemistry and neurodegeneration. Chem. Soc. Rev. 2013, 42, 1836-1846. [CrossRef] [PubMed]

22. Ma, G.; Wang, E.; Wei, H.; Wei, K.; Zhu, P.; Liu, Y. PtCl2(phen) disrupts the metal ions binding to amyloid-beta peptide. Metallomics 2013, 5, 879-887. [CrossRef] [PubMed]

23. Pithadia, A.S.; Lim, M.H. Metal-associated amyloid-beta species in Alzheimer's disease. Curr. Opin. Chem. Biol. 2012, 16, 67-73. [CrossRef] [PubMed] 
24. Hureau, C.; Faller, P. Platinoid complexes to target monomeric disordered peptides: A forthcoming solution against amyloid diseases? Dalton Transact. 2014, 43, 4233-4237. [CrossRef]

25. Man, B.Y.W.; Chan, H.M.; Leung, C.H.; Chan, D.S.H.; Bai, L.P.; Jiang, Z.H.; Li, H.W.; Ma, D.L. Group 9 metal-based inhibitors of beta-amyloid (1-40) fibrillation as potential therapeutic agents for Alzheimer's disease. Chem. Sci. 2011, 2, 917-921. [CrossRef]

26. Liu, H.; Qu, Y.W.; Wang, X.H. Amyloid beta-targeted metal complexes for potential applications in Alzheimer's disease. Future Med. Chem. 2018, 10, 679-701. [CrossRef] [PubMed]

27. Messori, L.; Camarri, M.; Ferraro, T.; Gabbiani, C.; Franceschini, D. Promising in Vitro anti-Alzheimer Properties for a Ruthenium(III) Complex. ACS Med. Chem. Lett. 2013, 4, 329-332. [CrossRef]

28. Jones, M.R.; Mu, C.; Wang, M.C.; Webb, M.I.; Walsby, C.J.; Storr, T. Modulation of the Abeta peptide aggregation pathway by KP1019 limits Abeta-associated neurotoxicity. Metallomics 2015, 7, 129-135. [CrossRef]

29. Yellol, G.S.; Yellol, J.G.; Kenche, V.B.; Liu, X.M.; Barnham, K.J.; Donaire, A.; Janiak, C.; Ruiz, J. Synthesis of 2-pyridyl-benzimidazole iridium(III), ruthenium(II), and platinum(II) complexes. study of the activity as inhibitors of amyloid-beta aggregation and neurotoxicity evaluation. Inorgan. Chem. 2015, 54, 470-475. [CrossRef]

30. Kang, J.; Lee, S.J.; Nam, J.S.; Lee, H.J.; Kang, M.G.; Korshavn, K.J.; Kim, H.T.; Cho, J.; Ramamoorthy, A.; Rhee, H.W.; et al. An Iridium(III) Complex as a Photoactivatable Tool for Oxidation of Amyloidogenic Peptides with Subsequent Modulation of Peptide Aggregation. Chemistry 2017, 23, 1645-1653. [CrossRef]

31. Heffern, M.C.; Velasco, P.T.; Matosziuk, L.M.; Coomes, J.L.; Karras, C.; Ratner, M.A.; Klein, W.L.; Eckermann, A.L.; Meade, T.J. Modulation of amyloid-beta aggregation by histidine-coordinating Cobalt(III) Schiff base complexes. ChemBioChem 2014, 15, 1584-1589. [CrossRef]

32. Derrick, J.S.; Lee, J.; Lee, S.J.; Kim, Y.; Nam, E.; Tak, H.; Kang, J.; Lee, M.; Kim, S.H.; Park, K.; et al. Mechanistic Insights into Tunable Metal-Mediated Hydrolysis of Amyloid-beta Peptides. J. Am. Chem. Soc. 2017, 139, 2234-2244. [CrossRef] [PubMed]

33. Sasaki, I.; Bijani, C.; Ladeira, S.; Bourdon, V.; Faller, P.; Hureau, C. Interference of a new cyclometallated Pt compound with Cu binding to amyloid-beta peptide. Dalton Transact. 2012, 41, 6404-6407. [CrossRef] [PubMed]

34. Collin, F.; Sasaki, I.; Eury, H.; Faller, P.; Hureau, C. Pt(II) compounds interplay with Cu(II) and Zn(II) coordination to the amyloid-beta peptide has metal specific consequences on deleterious processes associated to Alzheimer's disease. Chem. Commun. 2013, 49, 2130-2132. [CrossRef] [PubMed]

35. Ma, G.; Huang, F.; Pu, X.; Jia, L.; Jiang, T.; Li, L.; Liu, Y. Identification of [PtCl2(phen)] binding modes in amyloid-beta peptide and the mechanism of aggregation inhibition. Chemistry 2011, 17, 11657-11666. [CrossRef] [PubMed]

36. Kumar, A.; Moody, L.; Olaivar, J.F.; Lewis, N.A.; Khade, R.L.; Holder, A.A.; Zhang, Y.; Rangachari, V. Inhibition of Abeta42 peptide aggregation by a binuclear ruthenium(II)-platinum(II) complex: Potential for multi-metal organometallics as anti-amyloid agents. ACS Chem. Neurosci. 2010, 2010, 691-701. [CrossRef] [PubMed]

37. Pinato, O.; Musetti, C.; Sissi, C. Pt-based drugs: The spotlight will be on proteins. Metallomics 2014, 6, 380-395. [CrossRef]

38. Wang, X.; Zhu, D.; Zhao, C.; He, L.; Du, W. Inhibitory effects of NAMI-A-like ruthenium complexes on prion neuropeptide fibril formation. Metallomics 2015, 7, 837-846. [CrossRef]

39. Gong, G.H.; Wang, W.J.; Du, W.H. Binuclear ruthenium complexes inhibit the fibril formation of human islet amyloid polypeptide. Rsc. Adv. 2017, 7, 18512-18522. [CrossRef]

40. Zhu, D.; Gong, G.; Wang, W.; Du, W. Disaggregation of human islet amyloid polypeptide fibril formation by ruthenium polypyridyl complexes. J. Inorgan. Biochem. 2017, 170, 109-116. [CrossRef]

41. Gong, G.; Du, W.; Xu, J.; Huang, X.; Yin, G. Regulation of heteronuclear Pt-Ru complexes on the fibril formation and cytotoxicity of human islet amyloid polypeptide. J. Inorgan. Biochem. 2018, 189, 7-16. [CrossRef] [PubMed]

42. Hildebrandt, J.; Hafner, N.; Gorls, H.; Kritsch, D.; Ferraro, G.; Durst, M.; Runnebaum, I.B.; Merlino, A.; Weigand, W. Platinum(ii) $O, S$ complexes as potential metallodrugs against Cisplatin resistance. Dalton Transact. 2016, 45, 18876-18891. [CrossRef] [PubMed] 
43. Di Natale, C.; Scognamiglio, P.L.; Cascella, R.; Cecchi, C.; Russo, A.; Leone, M.; Penco, A.; Relini, A.; Federici, L.; Di Matteo, A.; et al. Nucleophosmin contains amyloidogenic regions that are able to form toxic aggregates under physiological conditions. FASEB J. 2015, 29, 3689-3701. [CrossRef] [PubMed]

44. Russo, A.; Diaferia, C.; La Manna, S.; Giannini, C.; Sibillano, T.; Accardo, A.; Morelli, G.; Novellino, E.; Marasco, D. Insights into amyloid-like aggregation of $\mathrm{H} 2$ region of the C-terminal domain of nucleophosmin. Biochim. Biophys. Acta 2017, 1865, 176-185. [CrossRef] [PubMed]

45. Scognamiglio, P.L.; Di Natale, C.; Leone, M.; Cascella, R.; Cecchi, C.; Lirussi, L.; Antoniali, G.; Riccardi, D.; Morelli, G.; Tell, G.; et al. Destabilisation, aggregation, toxicity and cytosolic mislocalisation of nucleophosmin regions associated with acute myeloid leukemia. Oncotarget 2016, 7, 59129-59143. [CrossRef] [PubMed]

46. De Santis, A.; La Manna, S.; Krauss, I.R.; Malfitano, A.M.; Novellino, E.; Federici, L.; De Cola, A.; Di Matteo, A.; D'Errico, G.; Marasco, D. Nucleophosmin-1 regions associated with acute myeloid leukemia interact differently with lipid membranes. Biochim. Biophys. Acta 2018, 1862, 967-978. [CrossRef] [PubMed]

47. La Manna, S.; Roviello, V.; Scognamiglio, P.L.; Diaferia, C.; Giannini, C.; Sibillano, T.; Morelli, G.; Novellino, E.; Marasco, D. Amyloid fibers deriving from the aromatic core of C-terminal domain of nucleophosmin 1. Int. J. Biol. Macromol. 2018, 122, 517-525. [CrossRef]

48. Di Natale, C.; La Manna, S.; Malfitano, A.M.; Di Somma, S.; Florio, D.; Scognamiglio, P.L.; Novellino, E.; Netti, P.A.; Marasco, D. Structural insights into amyloid structures of the C-terminal region of nucleophosmin 1 in type A mutation of acute myeloid leukemia. Biochim. Biophys. Acta 2019. [CrossRef]

49. Balbirnie, M.; Grothe, R.; Eisenberg, D.S. An amyloid-forming peptide from the yeast prion Sup35 reveals a dehydrated beta-sheet structure for amyloid. Proc. Nat. Acad. Sci. USA 2001, 98, 2375-2380. [CrossRef]

50. Iversen, L.L.; Mortishire-Smith, R.J.; Pollack, S.J.; Shearman, M.S. The toxicity in vitro of beta-amyloid protein. Biochem. J. 1995, 311, 1-16. [CrossRef]

51. Pica, A.; Leone, S.; Di Girolamo, R.; Donnarumma, F.; Emendato, A.; Rega, M.F.; Merlino, A.; Picone, D. $\mathrm{pH}$ driven fibrillar aggregation of the super-sweet protein Y65R-MNEI: A step-by-step structural analysis. Biochim. Biophys. Acta Gener. Subj. 2018, 1862, 808-815. [CrossRef] [PubMed]

52. Portillo, A.; Hashemi, M.; Zhang, Y.; Breydo, L.; Uversky, V.N.; Lyubchenko, Y.L. Role of monomer arrangement in the amyloid self-assembly. Biochim. Biophys. Acta 2015, 1854, 218-228. [CrossRef] [PubMed]

53. Davis, T.J.; Soto-Ortega, D.D.; Kotarek, J.A.; Gonzalez-Velasquez, F.J.; Sivakumar, K.; Wu, L.; Wang, Q.; Moss, M.A. Comparative study of inhibition at multiple stages of amyloid-beta self-assembly provides mechanistic insight. Mol. Pharm. 2009, 76, 405-413. [CrossRef] [PubMed]

54. Skiba, J.; Bernas, T.; Trzybinski, D.; Wozniak, K.; Ferraro, G.; Marasco, D.; Merlino, A.; Shafikov, M.Z.; Czerwieniec, R.; Kowalski, K. Mitochondria Targeting with Luminescent Rhenium(I) Complexes. Molecules 2017, 22, 809. [CrossRef] [PubMed]

55. Silveira, J.R.; Raymond, G.J.; Hughson, A.G.; Race, R.E.; Sim, V.L.; Hayes, S.F.; Caughey, B. The most infectious prion protein particles. Nature 2005, 437, 257-261. [CrossRef] [PubMed]

56. Wang, X.H.; Wang, X.Y.; Zhang, C.L.; Jiao, Y.; Guo, Z.J. Inhibitory action of macrocyclic platiniferous chelators on metal-induced A beta aggregation. Chem. Sci. 2012, 3, 1304-1312. [CrossRef]

57. Doti, N.; Scognamiglio, P.L.; Madonna, S.; Scarponi, C.; Ruvo, M.; Perretta, G.; Albanesi, C.; Marasco, D. New mimetic peptides of the kinase-inhibitory region (KIR) of SOCS1 through focused peptide libraries. Biochem. J. 2012, 443, 231-240. [CrossRef]

(C) 2019 by the authors. Licensee MDPI, Basel, Switzerland. This article is an open access article distributed under the terms and conditions of the Creative Commons Attribution (CC BY) license (http://creativecommons.org/licenses/by/4.0/). 